\title{
Laboratory Investigation of Rheological Properties of Polymer and Crude Oil
}

\author{
Clifford Tamuno-Ibime Dexterity* \\ Department of Petroleum Engineering, Rivers state University, Nigeria
}

Submission: July 29, 2017, Published: September 12, 2017

*Corresponding author: Clifford Tamuno-Ibime Dexterity, Department of Petroleum Engineering, Rivers state University, Port Harcourt, Nigeria, Email: dexterityclifford@gmail.com

\begin{abstract}
By analyzing the rheological properties of polymer and crude oil, it was found that polymer action on different crude samples vary with respect to fluid type. Fluid resistance to flow decreased after 0.01Molar Concentration of polymer (Xanthan gum) was used to form a buffer solution with $500 \mathrm{mls}$ of water kept for a period of 7 days. $400 \mathrm{mls}$ of the buffer solution formed with Xanthan gum $+200 \mathrm{mls}$ of each crude oil sample were used to make an investigation of the rheological properties of the polymer and crude oil. The Rheology of the crude samples, buffer solution and the crude oil samples + buffer solution were recorded at a constant temperature of $25^{\circ} \mathrm{C}$ was also taken.The growth of microbes was discovered after 7 days this microbes further reduced the resistant to fluid flow by breaking the heavy hydrocarbon molecules, compared to their initial viscosities. The viscosity of fluid flow was monitored via shear stresses in relation to different shear rates using the Power Law Model which graphically interprets how the fluid responds to shear thinning, monitored at different revolutions per minute (rpm) was discovered to give best response at a high shear rate of 600rpm.The investigation of the fluid flow was done by modeling a simulated reservoir using sandstone tube from Darcy's equation for fluid diffusivity which confirms that a decrease in viscosity causes an increase in the flow rate with the assumption made that fluid flow rate equals production rate. The xanthan gum polymer is preferably used because it is cost effective and environmentally friendly.
\end{abstract}

Keywords: Xanthan gum; Viscosity; Shear thinning; Microbes; Flow rate

\section{Introduction}

Rheology gives a proper knowledge of fluid flow behaviors. It is generally, the study of how matter deforms and flows, including its elasticity, plasticity and viscosity. In geology, rheology is particularly important in studies of moving ice, water, salt and magma, as well as in studies of deforming rocks. Rheological modeling of fluids in the field is visually described by the Bingham plastic or the power law model. Although this model is fairly easy to solve for its specific descriptive parameters, they do not simulate fluid behavior across the entire rheological spectrum very well, particularly in the low shear rate range [1].

The following definitions help in understanding this model:

- Shear rate $(\gamma)$ in a simple flow is the change in fluid velocity divided by the gap or width of the channel through which fluid is moving.

- $\quad$ Shear stress $(\tau)$ is the force per unit area required to move a fluid at a given shear rate.

- $\quad$ Fluid viscosity $(\mu)$ is the fluid's shear stress divided by the corresponding shear rate

- $\quad$ The power law Model (PL) characterizes mud behavior across the entire shear rate range.

\section{Plastic viscosity (PV)}

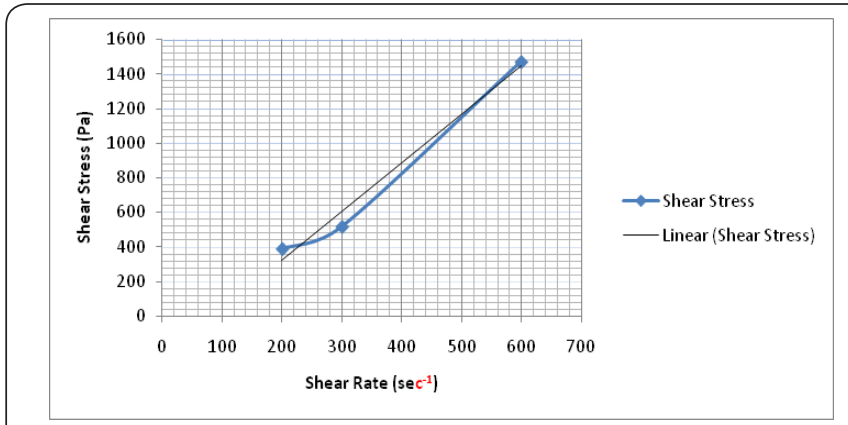

Figure 1: Shear stress vs shear rate.

${ }^{* *}$ From the graph above, slope $=$ Plastic Viscosity.

Plastic Viscosity (PV) is a resistance of fluid to flow. According to the Bingham plastic model, the PV is the slope of shear stress and shear rate (Figure 1). (Drilling formulas: Viscosity of drilling mud) [2]. Typically, the viscometer is utilized to measure shear rates at $600,300,200,100,6$, and 3 revolutions per minute ( $\mathrm{rpm}$ ). With increased use of polymerbased fluids in the oil field, the power law (PL) model became popular because it fits the behavior of these fluids better than the Bingham plastic model. The model's relationship between shear stress and shear rate is given by 
Shear stress $=\mathrm{K} \times(\text { shear rate })^{\mathrm{n}}$

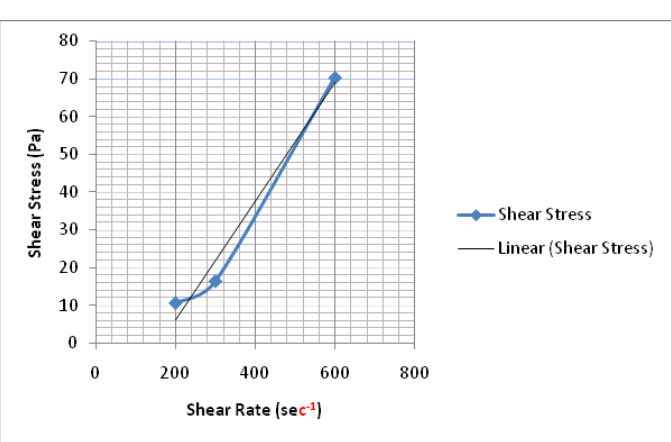

Figure 2: Shear stress vs shear rate (after 7days).

The two key terms in the PL model are the consistency index (K) and the fluid flow index (n). Although the model fairly accurately predicts fluid behavior at the higher shear rates, it fails across the lower shear rate range $(0-100 \mathrm{rpm})$. Moreover, people who use the PL model recognize that different values of $\mathrm{n}$ are possible, depending on which particular shear stress/ shear rate pairs are used in the calculation methods. $\mathrm{n}$ and $\mathrm{K}$ can be calculated from any two value of shear rate and shear stress. The method of reading shear rate on the rig comes from a V-G meter (Figure 2). Typically, 600rpm, 300rpm and 3rpm are obtained from every fluid rheology test and we can use those reading to determine $\mathrm{n}$ and $\mathrm{K}$. The following equations are used to get the Power law constants ( $\mathrm{n}$ and $\mathrm{K}$ ).

Shear stress $=\mathrm{K} \times(\text { shear rate })^{\mathrm{n}}$

Where;

$\mathrm{n}=3.23 \log (\theta 600 / \theta 300)$

$\mathrm{K}=5.11\left(\right.$ Reading at $\left.300 / 511^{\mathrm{n}}\right)$

$\mathrm{n}$ is the power law exponent. (Flow behavior index) dimensionless

$\mathrm{K}=$ consistency factor, (poise)

$\theta 300=$ reading at $300 \mathrm{rpm}$

$\theta 600=$ reading at $600 \mathrm{rpm}$

A graph of shear stress against shear rate was plotted to consider the rate of flow which explains the Power Law Model better was aided by the Darcy's equation for an unsteady state process. The most commonly used fluid model to determine the rheology of non-Newtonian fluid is the Bingham plastic model. With this model, it makes the assumption that the shear rate is a straight line function of the shear stress. The point where the shear rate is zero is called "Yield Point" or threshold stress. (Drilling fluid formulas: types of flow and rheology models) [3].

\section{Darcy equation in petroleum engineering}

The Darcy Equation in fluid diffusivity for an unsteady state process is introduced to predict fluid flow showing how flow rate varies inversely with viscosity. Also, a simulated reservoir sytem was modelled to note the conditions through which the fluid flows and their various viscosities recorded.

$$
Q=(-K A) / \mu d P / d x
$$

The Darcy Equation was introduced to note the resistance to flow of the fluid samples (crude oil + a buffer solution made with xanthan gum) through permeable media. This was done in a one dimensional, homogenous rock formation (sandstone) for an unsteady state process.

Assuming flow rate $=$ Production rate

$$
\begin{aligned}
& \mathrm{qSC}=\left((\mathrm{KA}) /\left(\mu \mathrm{B} \Delta \mathrm{x}^{2}\right)\right) \times \mathrm{P}_{\mathrm{i}}-1-2 \mathrm{P}_{\mathrm{i}}+\mathrm{P}_{\mathrm{i}}+1 \\
& \mathrm{q}=\lambda^{1} \Delta \mathrm{P}^{\mathrm{i}}
\end{aligned}
$$

The equation was further derived showing how flow rate varies with viscosity.

\section{Materials and Method \\ Crude oil samples}

3 Different Niger Delta Crude oil samples were obtained and worked on.

1. SAMPLE A - AGBDZ (0375) from Agbada Field.

2. SAMPLE B -IMOR- E (5133)

3. SAMPLE C - GBAR (0015)

Decantation: Decantation of crude sample was carried out. Decantation is the removal of water from the various crude samples.

Polymer used: The Polymer used in this experiment is Xanthan gum. XG is made up of strains of bacteria (Xanthomonas campestris) from the fermentation process of simple sugars. Xanthan gum of 0.01 Molar Concentration was gotten to prepare a buffer solution with $500 \mathrm{mls}$ of water.

Buffer solution: A buffer solution of 0.01Molar Concentration of Xanthan gum $+500 \mathrm{mls}$ of water were made to break the hydrocarbon molecules of the crude samples without altering the hydrocarbon $\mathrm{pH}$ and at a constant temperature of $25{ }^{\circ} \mathrm{C}$.

Viscosity determination: Viscosity was determined using a Fan Viscometer (Rheometer) at; $400 \mathrm{mls}$ of Crude oil sample $+200 \mathrm{mls}$ of Buffer Solution This was done to further aid the breakdown of hydrocarbon molecules of the crude samples; therefore, a mixture of the $100 \mathrm{mls}$ of water $+100 \mathrm{mls}$ of the buffer solution was also made due to the increase of viscosity after 7 days at a constant temperature of $25^{\circ} \mathrm{C}$.

\section{Results and Discussion}

\section{Rheology}

Rheology gives a better explanation of the fluid behavior under different conditions. The viscosity of each crude sample was recorded. Also, the viscosity of the buffer solution was 


\section{Recent Advances in Petrochemical Science}

recorded and finally, the viscosity of the mixture of each crude sample and the buffer solution was also recorded $(400 \mathrm{mls}$ of crude oil sample $+200 \mathrm{mls}$ of Buffer solution) at a constant temperature of $25{ }^{\circ} \mathrm{C}$. The Shear Stress for the various crude oil samples + Buffer solution was recorded as shown from the Table 1: $1^{\text {st }}$ Rheological readings.

\begin{tabular}{|c|c|c|c|c|c|c|c|}
\hline $\begin{array}{l}\text { Buffer } \\
\text { Solution }\end{array}$ & $\begin{array}{l}\text { Buffer } \\
\text { Solution }\end{array}$ & $\begin{array}{c}\text { Sample A } \\
\text { (Agbdz- 0375) }\end{array}$ & $\begin{array}{c}\text { Sample B } \\
\text { (Imor-E 5133) }\end{array}$ & $\begin{array}{c}\text { Sample C } \\
\text { (Gbar- 0015) }\end{array}$ & $\begin{array}{l}\text { Sample A } \\
\text { + Buffer } \\
\text { Solution }\end{array}$ & $\begin{array}{l}\text { Sample B } \\
\text { + Buffer } \\
\text { Solution }\end{array}$ & $\begin{array}{l}\text { Sample C } \\
\text { + Buffer } \\
\text { Solution }\end{array}$ \\
\hline$\Theta 600$ & 294 & 260 & 46 & 9 & 330 & 114 & 102 \\
\hline$\Theta 300$ & 199 & 139 & 23 & 5 & 276 & 98 & 70 \\
\hline$\Theta 200$ & 167 & 96 & 16 & 3 & 188 & 82 & 56 \\
\hline$\Theta 100$ & 127 & 50 & 8 & 2 & 99 & 42 & 46 \\
\hline$\Theta 60$ & 105 & 31 & 5 & 2 & 62 & 32 & 42 \\
\hline$\Theta 30$ & 81 & 11 & 2.5 & 1 & 32 & 20 & 30 \\
\hline$\Theta 6$ & 44 & 4 & 1 & 1 & 7 & 6 & 18 \\
\hline$\Theta 3$ & 33 & 2 & 0.8 & 0.5 & 4 & 4 & 6 \\
\hline \multicolumn{8}{|l|}{ Gel } \\
\hline (10Secs.) & 33 & 2 & 0.8 & 0.5 & 4 & 4 & 6 \\
\hline $\mathrm{PV}$ & 95 & 121 & 20 & 4 & 54 & 16 & 32 \\
\hline YP & 24 & 81 & 3 & 1 & 222 & 82 & 38 \\
\hline $\begin{array}{l}\text { Shear stress } \\
\qquad(\mathrm{Pa})\end{array}$ & - & - & - & - & 1462.02 & 511.08 & 394.08 \\
\hline
\end{tabular}

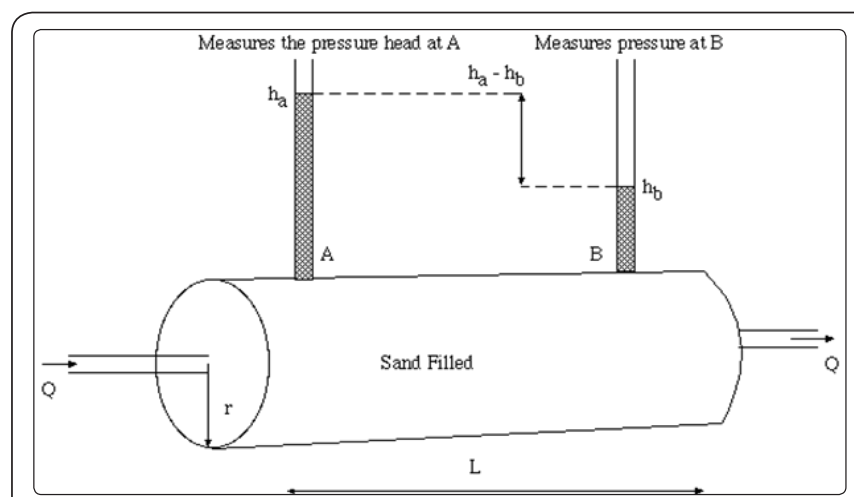

Figure 3A: Darcy's fluid flow diagram.

This could also be interpreted by the graph of shear stress vs shear rate which yields a consistency curve that best explains the fluid flow behavior and type (Figure 3A). The Table 2: Rheology after 7days.

\begin{tabular}{|c|c|c|c|c|}
\hline Readings (Cp) & Buffer Solution & $\begin{array}{c}\text { Sample A + Buffer } \\
\text { Solution }\end{array}$ & $\begin{array}{c}\text { Sample B + Buffer } \\
\text { Solution }\end{array}$ & $\begin{array}{c}\text { Sample C + Buffer } \\
\text { Solution }\end{array}$ \\
\hline$\theta 600$ & 64 & 20 & 4 & 2.5 \\
\hline$\theta 300$ & 50 & 12 & 3 & 2 \\
\hline$\theta 200$ & 45 & 9 & 1.4 & 1 \\
\hline$\theta 100$ & 39 & 5 & 0.7 & 1 \\
\hline$\theta 60$ & 35 & 3 & 0.4 & 0.8 \\
\hline$\theta 30$ & 31 & 2 & 0.3 & 0.6 \\
\hline$\theta 3$ & 25 & 0.4 & 0.1 & 0.5 \\
\hline
\end{tabular}

consistency curve has the exponential equation as described by the equation,

Shear stress $=\mathrm{K} \times(\text { shear rate })^{\mathrm{n}}$

Shear rate $=600 \mathrm{rpm}\{$ highest shear rate $($ Speed $)$ from the Viscometer\}

$\mathrm{n}=3.23 \log (\theta 600 / \theta 300)$

$\mathrm{K}=5.11($ Reading at 300/511n)

$\mathrm{K}$ is the fluid consistency unit and $\mathrm{n}$ is the power law exponent.

Solution using the power law model equation: The shear stress for the various Samples + Buffer Solution Made up of Polymer (Xanthan gum) and water is shown in the Power Law Calculations Below (Table 2).

The shear stress was gotten from the fluid (non-Newtonian) from the Consistency curve plotted by shear stress against the Shear rate [4]. . 


\section{Recent Advances in Petrochemical Science}

\begin{tabular}{|c|c|c|c|c|}
\hline Gel (10Secs.) & 23 & 0.2 & 0.1 & 0.5 \\
\hline PV & 14 & 8 & 1 & 0.5 \\
\hline YP & 24 & 4 & 2 & 1.5 \\
\hline Shear stress (Pa) & 276.61 & 70.34 & 16.34 & 10.54 \\
\hline
\end{tabular}

$1^{\text {st }}$ Observation:

Table 3: Summary of result.

\begin{tabular}{|c|c|c|c|c|c|}
\hline Samples & $\begin{array}{c}\mu \\
\text { (Before) Cp }\end{array}$ & $\begin{array}{c}Q \text { (Before) } \\
\mathrm{Ft}^{3} / \mathrm{Sec}\end{array}$ & $\begin{array}{c}\mu \\
\text { (After 7days) Cp }\end{array}$ & $\begin{array}{c}\mathrm{Q} \\
\text { (After 7days) } \mathrm{Ft}^{3} / \mathrm{Sec}\end{array}$ & $\begin{array}{c}\text { Percentage } \\
\text { Deviation (\%) }\end{array}$ \\
\hline A & 54 & 0.00094 & 8 & 0.0064 & 85.3 \\
\hline B & 16 & 0.00313 & 1 & 0.05 & 93.7 \\
\hline $\mathrm{C}$ & 32 & 0.00158 & 0.4 & 0.126 & 98.9 \\
\hline
\end{tabular}

Only Sample A formed a soluble (very viscous) solution after shearing the $400 \mathrm{mls}$ of Crude $+200 \mathrm{mls}$ Buffer solution (Table 3).

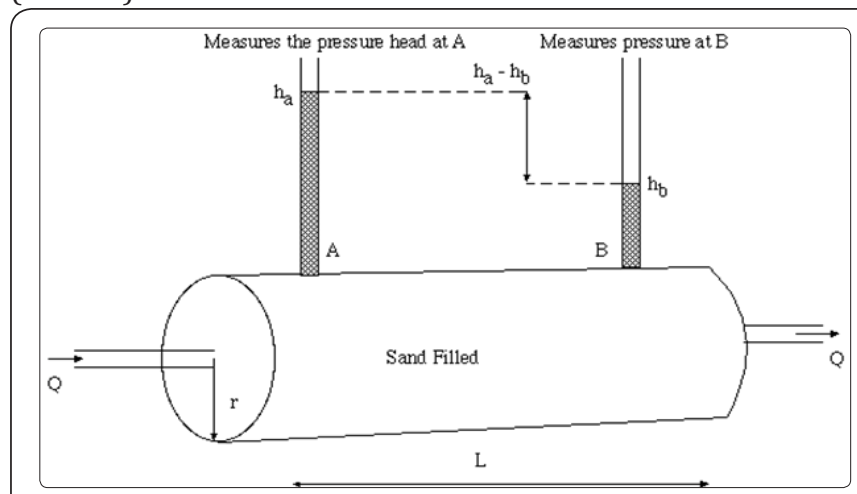

Figure 3B: Darcy's fluid flow diagram.

After taken the viscosity readings of the samples, they were left for 7 days to see the behavioral patterns/properties of the samples. Therefore, rheology was carried out to note their various viscosities. The table below shows the result after 7days (Figure 3B).

From the experiment carried out, the viscosity of the buffer solution (Xanthan gum +water) decreases with higher shear rates. This is called shear thinning or pseudo-plasticity.

Once the shear forces are removed, the buffer starts to thicken thereby increasing viscosity. NB: The shear stress was gotten from the Power Law Model; this describes the characteristics of the fluid (non Newtonian) [5]. The consistency curve has the exponential equation as described by the equation

Shear stress $=\mathrm{K} \times(\text { shear } \text { rate })^{\mathrm{n}}$

Shear rate $=600$ (highest shear rate from the Viscometer)

$\mathrm{n}=3.23 \log (\theta 600 / \theta 300)$

$\mathrm{K}=5.11(\theta 300 / 511 \mathrm{n})$

The shear stress for the various Samples + Buffer Solution Made up of Polymer (Xanthan gum) and water after 7 Daysis shown in the Power Law Calculation Below (Table 4).
Table 4: Solution using the power law model equation.

\begin{tabular}{|c|c|c|}
\hline For Sample A & For Sample B & For Sample C \\
\hline $\begin{array}{c}\text { Shear stress }=K \\
\times \gamma n\end{array}$ & $\begin{array}{c}\text { Shear stress }=K \\
\times \gamma n\end{array}$ & $\begin{array}{c}\text { Shear stress }=K \\
\times \gamma n\end{array}$ \\
\hline $\begin{array}{c}n=3.23 \mathrm{Log} \\
(330 / 276)\end{array}$ & $\begin{array}{c}n=3.23 \log \\
(114 / 98)\end{array}$ & $\begin{array}{c}n=3.23 \log \\
(102 / 70)\end{array}$ \\
\hline $\mathrm{n}=3.23 \log (1.196)$ & $\mathrm{n}=3.23 \log (1.163)$ & $\mathrm{n}=3.23 \log (1.46)$ \\
\hline $\mathrm{n}=3.23 \quad 0.078$ & $\mathrm{n}=3.230 .066$ & $\mathrm{n}=3.23$ \\
\hline $\mathrm{n}=0.25$ & $\mathrm{n}=0.21$ & $\mathrm{n}=0.53$ \\
\hline Therefore, & Therefore, & Therefore, \\
\hline $\mathrm{K}=5.11\left(\theta 300 / 511^{\mathrm{n}}\right)$ & $K=5.11\left(\theta 300 / 511^{n}\right)$ & $K=5.11\left(\theta 300 / 511^{n}\right)$ \\
\hline$K=5.11\left(276 / 511^{0.25}\right)$ & $K=5.11\left(98 / 511^{0.25}\right)$ & $K=5.11\left(70 / 511^{0.53}\right)$ \\
\hline$K=5.1157 .81$ & $K=5.11 \times 26.10$ & $\mathrm{~K}=5.11 \times 2.60$ \\
\hline$K=295.411$ poise & $\mathrm{K}=133.375$ poise & $\mathrm{K}=13.279$ poise \\
\hline $\begin{array}{c}\text { Shear stress }(\tau)=\mathrm{K} \times \\
\gamma \mathrm{n}\end{array}$ & $\begin{array}{c}\text { Shear stress }(\tau)=K \times \\
\gamma n\end{array}$ & $\begin{array}{c}\text { Shear stress }(\tau)=\mathrm{K} \times \\
\gamma \mathrm{n}\end{array}$ \\
\hline$\tau=295.411 \times 600^{0.25}$ & $\tau=295.411 \times 600^{0.21}$ & $\tau=13.279 \times 600^{0.69}$ \\
\hline$\tau=1462.06 \mathrm{~Pa}$ & $\tau=511.08 \mathrm{~Pa}$ & $\tau=394.08 \mathrm{~Pa}$ \\
\hline
\end{tabular}

\section{$2^{\text {nd }}$ observation:}

After 7 days, the viscosity reduced drastically as a result of the growth of microbes which was very visible in the crude samples and much more visible on the buffer solution (Xanthan Gum + water).

The buffer solution was discovered to be very viscous so an additional $100 \mathrm{mls}$ of water was added to it to reduce viscosity which made it to be a solution of $100 \mathrm{mls}$ of water $+200 \mathrm{mls}$ of buffer solution and the rheology was taken to see the rate of flow and carrying capacity to see if the hydrocarbon can be swept into the reservoir [6].

The hydrocarbon molecules were broken down as a result of the polymer action and growth of microbes after a mixture is formed with the crude oil samples due to a higher shear rate.

The breakdown of the hydrocarbon molecules resulted to an increase in flow (Table 5). 
Table 5: The shear stress for the various Samples + Buffer Solution Made up of Polymer (Xanthan gum) and water after 7 Daysis shown in the Power Law Calculation.

\begin{tabular}{|c|c|c|}
\hline For Sample A & For Sample B & For Sample C \\
\hline $\begin{array}{c}\text { Shear stress }=K \times \\
K \times \gamma n\end{array}$ & (After 7 Days) & (After 7 Days) \\
\hline $\begin{array}{c}n=3.23 \mathrm{Log} \\
(330 / 276)\end{array}$ & $\begin{array}{c}\text { Shear stress }=K \times K \\
\times \gamma n\end{array}$ & $\begin{array}{c}\text { Shear stress }=K \times \\
K \times \gamma n\end{array}$ \\
\hline $\mathrm{n}=3.23 \log (1.196)$ & $n=3.23 \log (4 / 3)$ & $\mathrm{n}=3.23 \log (2.5 / 2)$ \\
\hline $\mathrm{n}=3.23$ & $\mathrm{n}=3.23 \log (1.333)$ & $\mathrm{n}=3.23 \log (1.25)$ \\
\hline $\mathrm{n}=0.25$ & $\mathrm{n}=3.23$ & $\mathrm{n}=3.23$ \\
\hline Therefore, & $\mathrm{n}=0.40$ & $\mathrm{n}=0.31$ \\
\hline$K=5.11\left(\theta 300 / 511^{\mathrm{n}}\right)$ & Therefore, & Therefore, \\
\hline$K=5.11\left(276 / 511^{0.25}\right)$ & $K=5.11\left(\theta 300 / 511^{\mathrm{n}}\right)$ & $\mathrm{K}=5.11\left(\theta 300 / 511^{\mathrm{n}}\right)$ \\
\hline$K=5.11 \times 57.81$ & $K=5.11\left(3 / 511^{0.40}\right)$ & $K=5.11$ \\
\hline$K=295.411$ poise & $K=5.11 \times 0.24$ & $\mathrm{~K}=1.451$ poise \\
\hline $\begin{array}{l}\text { Shear stress }(\tau) \\
=K \times \gamma n\end{array}$ & $\begin{array}{l}\text { Shear stress }(\tau) \\
=K \times \gamma n\end{array}$ & $\begin{array}{l}\text { Shearstress }(\tau) \\
=K \times \gamma n\end{array}$ \\
\hline$\tau=295.411 \times 600^{0.25}$ & $\tau=1.265 \times 600^{0.40}$ & $\tau=1.451 \times 600^{0.31}$ \\
\hline$\tau=1462.06 \mathrm{~Pa}$ & $\tau=16.34 \mathrm{~Pa}$ & $\tau=10.54 \mathrm{~Pa}$ \\
\hline
\end{tabular}

NB: The various crude samples were placed on flow condition using the Darcy's equation in fluid diffusivity for an unsteady state flow process to model a simulated hydrocarbon reservoir.

\section{Darcy equation in petroleum engineering}

In Petroleum Engineering, to determine the flow through permeable media the most simple of which is for a onedimensional, homogeneous rock formation. Recal Darcy Equation in fluid diffusivity equation for an unsteady state process

$\mathrm{Q}=(-\mathrm{KA}) / \mu \mathrm{dP} / \mathrm{dx}$

Where,

$\mathrm{Q}$ is the flow rate of the formation (in units of volume per unit time)

$\mathrm{K}$ is the permeability of the formation (typically in milliDarcy)

$A$ is the cross-sectional area of the formation

$\mu$ is the viscosity of the fluid (typically in units of centipoises)

$\partial \mathrm{p} / \partial \mathrm{x}$ represents the pressure change per unit length of the formation.

This equation can also be solved for permeability and is used to measure it, forcing a fluid of known viscosity through a core of a known length and area, the pressure drop across the length of the core. While the flow rate was monitored to see its outcome

\section{The simulated model:}

Darcy Equation of fluid diffusivity for an unsteady state process is given by

$$
Q=(-K A) / \mu d P / d x
$$

And the basic fluid flow equation in a porous media is also given by;

$\mathrm{d} / \mathrm{dx}((\mathrm{KA}) / \mu \mathrm{B} d \mathrm{P} / \mathrm{dx})+\mathrm{qsc}=\mathrm{Vb} \emptyset \mathrm{Ct} \operatorname{SwdP} / \mathrm{dx}$

For steady state, $\mathrm{dP} / \mathrm{dx}=0$

Therefore,

$d / d x((K A) / \mu B d P / d x)+q s c=0$

Simplifying equation (3) gives;

$\left(\mathrm{d}^{2} \mathrm{P}\right) /\left(\mathrm{dx}^{2}\right)((\mathrm{KA}) / \mu \mathrm{B})=-\mathrm{qsc}$.

Note that the negative sign indicates production.

Assuming fluid flow rate $=$ Production rate

Then,

$\mathrm{q}_{\mathrm{sc}}=\left((\mathrm{KA}) /\left(\mu \mathrm{B} \Delta \mathrm{x}^{2}\right)\right) \times \mathrm{P}_{\mathrm{i}-1}-2 \mathrm{P}_{\mathrm{i}}+\mathrm{P}_{\mathrm{i}+1}$

Let $\left((\mathrm{KA}) /\left(\mu \mathrm{B} \Delta \mathrm{x}^{2}\right)\right)=\lambda$

$\mathrm{q}_{\mathrm{sc}}=\lambda\left[\mathrm{P}_{\mathrm{i}-1}-2 \mathrm{P}_{\mathrm{i}}+\mathrm{P}_{\mathrm{i}+1}\right]$

Considering a First order derivative for Equation (4),

Equation (7) now becomes;

$\mathrm{q}=\lambda^{1}\left[\mathrm{P}_{\mathrm{i}+1}-\mathrm{P}_{\mathrm{i}}\right]$

Setting $\left[\mathrm{P}_{\mathrm{i}+1}-\mathrm{P}_{\mathrm{i}}\right]$ as $\Delta \mathrm{P}_{\mathrm{i}}=\mathrm{f}\left({ }_{\mathrm{i}, \mathrm{i}+1}\right)$...

Results to;

$\mathrm{q}=\lambda^{1} \Delta \mathrm{P}_{\mathrm{i}}$

Where,

$\lambda^{1}=((\mathrm{KA}) / \mu \mathrm{B} \Delta \mathrm{x})=$ specific transmissibility Constant. $\left(\mathrm{L}^{3}\right.$ $/ \mathrm{MT}^{-1}$ )

$(\mathrm{KA} /(\mu \mathrm{mB} \Delta \mathrm{x}))=\lambda^{1}$ with dimension $\left(\mathrm{L}^{3} / \mathrm{MT}^{-1}\right)$.

$\mathrm{K}=$ Permeability, (MD)

$A=$ Area open to flow, $\left(\mathrm{ft}^{2}\right)$

$\Delta \mathrm{P}=$ Change in pressure (psia)

$\mu_{\mathrm{m}}=$ Modified Crude oil Viscosity as a result of polymer action, (cp)

$\mathrm{B}=$ Oil Formation volume Factor (res-bbl/stb)

$\Delta \mathrm{x}=$ Length of Core Sample, $(\mathrm{ft})$. 
$\mathrm{q}_{\mathrm{p}}=$ Oil Flow rate as a result of Polymer Flooding, $\left(\mathrm{ft}^{3} / \mathrm{sec}\right)$.

\section{Consider the simulated reservoir system}

This is a condition that helps in the determination of the fluid flow behavior Simulated with the following parameters for fluid flow equation at the different fluid viscosities gotten from the experiment carried out

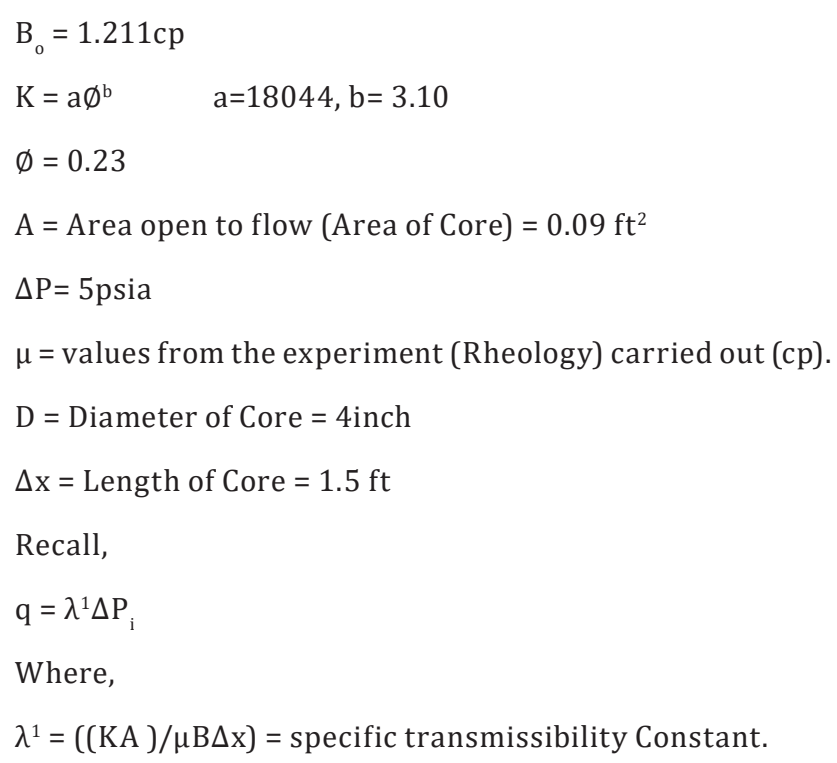

\section{For sample a:}

Where,

$\mathrm{B}_{\mathrm{o}}=1.12$

$\mu=54$ (at initial)

$\mu=8$ (After 7Days)

While every other parameter remains the same as stated above

$\lambda^{1}=((0.19 \times 0.09) /(54 \times 1.12 \times 1.5))=0.000188$

Therefore,

$\mathrm{q}=0.00188 \times 5$

$\mathrm{q}=0.00094 \mathrm{ft}^{3} / \mathrm{sec}$.

Sample A (After 7Days)

$\lambda^{1}=((0.19 \times 0.09) /(8 \times 1.12 \times 1.5))=0.00127$

Therefore,

$\mathrm{q}=0.00127 \times 5$

$\mathrm{q}=0.0064 \mathrm{ft}^{3} / \mathrm{sec}$.

Percentage deviation for sample a

$\% \mathrm{D}=0.00094 / 0.006 \times 100=14.7 \%$

For Sample A, the $\% \mathrm{D}=100-14.7=85.3 \%$

\section{For sample B:}

Where,

Bo $=1.14$

$\mu=16$ (at initial)

$\mu=1$ (After 7Days)

While every other parameter remains the same as stated above

$\lambda^{1}=((0.19 \times 0.09) /(16 \times 1.14 \times 1.5))=0.000625$

Therefore,

$\mathrm{q}=0.00625 \times 5$

$\mathrm{q}=0.00313 \mathrm{ft}^{3} / \mathrm{sec}$.

Sample B (After 7Days)

$\lambda^{1}=((0.19 \times 0.09) /(1 \times 1.14 \times 1.5))=0.01$

Therefore,

$\mathrm{q}=0.01 \times 5$

$q=0.05 \mathrm{ft} 3 / \mathrm{sec}$.

Percentage deviation for sample B

$\% \mathrm{D}=0.00313 / 0.05 \times 100=6.26 \%$

For Sample B, the $\% \mathrm{D}=100-6.26=93.7 \%$

For Sample C:

Where,

$\mathrm{B}_{\mathrm{o}}=1.13$

$\mu=32$ (at initial)

$\mu=0.4$ (After 7Days)

While every other parameter remains the same as stated above.

$\lambda^{1}=((0.19 \times 0.09) /(32 \times 1.13 \times 1.5))=0.000315$

Therefore,

$\mathrm{q}=0.00315 \times 5$

$\mathrm{q}=0.00158 \mathrm{ft} 3 / \mathrm{sec}$.

Sample C (After 7Days)

$\lambda^{1}=((0.19 \times 0.09) /(0.4 \times 1.13 \times 1.5))=0.025$

Therefore,

$q=0.025 \times 5$

$\mathrm{q}=0.126 \mathrm{ft}^{3} / \mathrm{sec}$.

Percentage Deviation for Sample C

$\% \mathrm{D}=0.00158 / 0.126 \times 100=1.25 \%$ 
For Sample C, the $\% \mathrm{D}=100-1.25=98.7 \%$

The breakdown of the hydrocarbon molecules by the buffer solution made up of polymer and water shows a significant effect on the fluid by drastically reducing the viscosity after the fluid has been subjected to high shear rate and placed on flow condition on a simulated reservoir system.

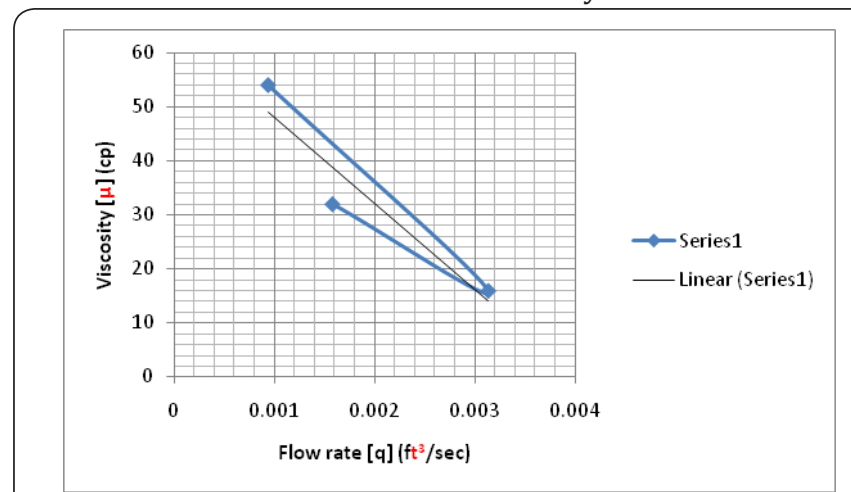

Figure 4: Graph of flow rate vs viscosity.

A graphical interpretation of the summary in the Figure 4 $\& 5$, better explains the result.

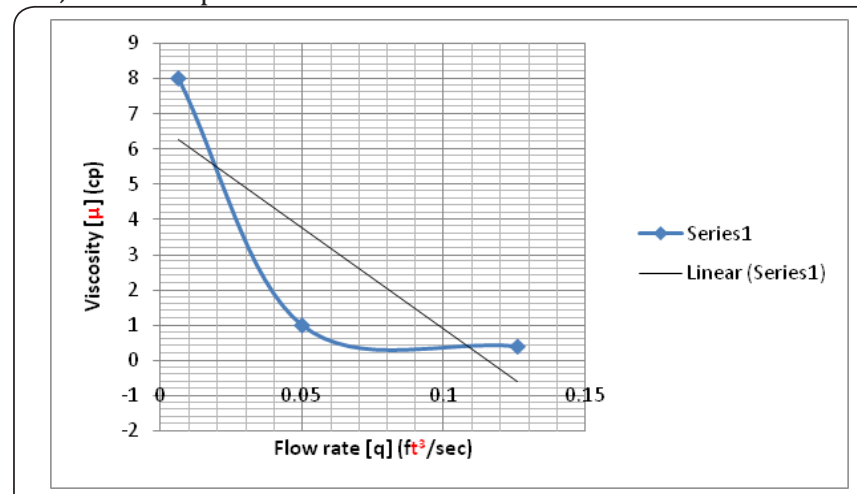

Figure 5: Graph of flow rate vs viscosity.

Figure 4 is a Graph indicating the trend of fluid flow; showing how Flow rate increases with decreasing Viscosity (Initially before 7 days), which also shows the effect of pseudoplasticity; this best describes the type of non-Newtonian flow, where viscosity falls with increasing shear rate. Most molten polymers are pseudo-plastic. The viscosity of Sample A was found to be higher compared to samples B and C despite the share rates. This means, the viscosity of polymer in solution decreases with higher shear rates, which yields a high flow rate [7].

From the result, the higher the viscosity, the lower the flow rate and the lower the viscosity, the higher the flow rate. This experiment proves that Sample $\mathrm{C}$ has the best flow rate because it has a viscosity of $0.4 \mathrm{cp}$ compared to the other Samples with a better percent deviation of $98.9 \%$ which means it has a very high ability to flow at $0.125 \mathrm{ft}^{3}$

/sec after 7 days compared to its initial flow rate of $0.00158 \mathrm{ft}^{3} / \mathrm{sec}$.

\section{Conclusion}

Xanthan gum is known to be a viscous polymer if subjected to flow once the shear forces are removed, the polymer in solution starts to thicken thereby increasing viscosity, also from the investigation carried out after 7 days, growth of microbes which was very visible in the crude samples and much more visible on the buffer solution had the ability to keep the hydrocarbon $\mathrm{pH}$ constant while the heavier molecules in the hydrocarbon are broken down which discovered to drastically increase fluid flow due to shear thinning or pseudo-plasticity.

The viscosity of Sample A was found to be higher compared to samples $\mathrm{B}$ and $\mathrm{C}$ despite the share rates. This means, the viscosity of polymer in solution decreases with higher shear rates, which yields a high flow rate. Therefore, polymers can be injected into a hydrocarbon reservoir to enhance oil recovery because it is cost effective and environmentally friendly.

\section{References}

1. Cristina-Eliza B, Berca M (2016) Some properties of Xanthan gum in aqueous solution: Effect of Temperature and $\mathrm{pH}$. Journal of Polymer Research 23: 123 .

2. Chukwuma NG (2014) Pore characterization of Niger-Delta sandstone formation by numerical methods. International Journal of Emerging Technology and Advanced Engineering 4(5): 488-493.

3. Chidiebere AO, Egwu E, Daraha T (2013) Laboratory Investigation of the effect of crude oil spill in Engineering Properties of concrete. IOSR Journal of Mechanical and Civil Engineering 10(2): 11-17.

4. Laneuville S, Turgeon SL, Paguin P (2012) Changes in the physical properties of Xanthan gum induced by dynamic high pressure treatment. Carbohydr Polym 92(2): 2327-2336.

5. Kang W, Wang D (2001) Emulsification characteristic and Demulsifiers Action for Alkaline/Surfactant/Polymer flooding.

6. Katzbauer B (1998) Polymer degradation and stability: properties and applications of xanthan gum. Oil field glossary Slb, Drilling fluid formulas.

7. http://www.googlebooks.com 


\section{Recent Advances in Petrochemical Science}

This work is licensed under Creative Commons Attribution 4.0 Licens DOI: 10.19080/RAPSCI.2017.02.555600
Your next submission with Juniper Publishers will reach you the below assets

- Quality Editorial service

- Swift Peer Review

- Reprints availability

- E-prints Service

- Manuscript Podcast for convenient understanding

- Global attainment for your research

- Manuscript accessibility in different formats

( Pdf, E-pub, Full Text, Audio)

- Unceasing customer service

Track the below URL for one-step submission https://juniperpublishers.com/online-submission.php 